\title{
Monitoring River Restoration Efforts: Do Invasive Alien Plants Endanger the Success? A Case Study of the Traisen River
}

\author{
Katharina Lapin, Karl-Georg Bernhardt, Elisabeth Mayer, Stefanie Roithmayr, \\ Joachim Neureiter, Claudia Horvath \\ Department of Integrative Biology and Biodiversity Research, Institute of Botany, University of Natural \\ Resources and Life Sciences, Vienna, Austria \\ Email: katharina.lapin@boku.ac.at
}

Received 26 March 2016; accepted 9 May 2016; published 12 May 2016

Copyright (C) 2016 by authors and Scientific Research Publishing Inc.

This work is licensed under the Creative Commons Attribution International License (CC BY).

http://creativecommons.org/licenses/by/4.0/

c) (†) Open Access

\begin{abstract}
River restoration activities are challenging for the native vegetation and the colonization process. The development of invasive alien plant species (IAS) as well as the development of the pioneer vegetation cover and seed bank were observed in one year prior to construction of a new river bed and within the first two years after construction, along the downstream section of the river Traisen in Austria. One year after completion of the new river channel, the occurrence of IAS above ground decreased while the occurrence of target species increased. Furthermore, no seeds of IAS were detected in the new river bed as a result of proper management of soil movement. Despite the positive impact on the abundance of IAS, the restoration project of the river Traisen shows that the fact that such a restoration activity is a disturbance event must be taken into consideration already during the planning process. Supporting the competitiveness of native plant species is an important tool for reducing the danger of establishment of invasive alien species.
\end{abstract}

\section{Keywords}

Landscape Management, Invasive Alien Plant Species, Riparian Area, River Restoration, Seed Bank, Vegetation, Succession

\section{Introduction}

The aim of river restoration programs is to create a healthy and self-sustaining river system providing important ecological and social functions [1] [2]. Many engineering solutions for successfully achieving river and stream 
restoration have been discussed [3] [4], but few studies address the risks and challenges for the native vegetation and the colonization process [5]. Restoration activities are regarded as disturbances that facilitate biological invasions, in particular for alien plant species [6] [7].

In recent years, there has been an increasing interest in the consequences of the spread of invasive alien species (IAS) [8]. According to the International Union for Conservation of Nature [IUCN], invasive alien species are the second most significant cause of extinction [9]. A large number of studies describe how alien species are consciously or unconsciously introduced into various environments by humans, and how they quickly establish themselves in these new habitats and contribute to a decrease in species diversity [10]-[12]. Over the past 40 years, damages to ecosystem services and human well-being from invasive alien species have increased dramatically [13]-[15]. Although it is well documented that IAS can have a significant effect on the relative abundance of native species, few studies discuss whether IAS are the main driver of changes in species compositions. Studies have shown that the spread of habitat loss and habitat modification are driving native species loss in first place [16]. River restoration programs became an important tool to reduce the negative effect of habitat loss [2]. In this context, we want to observe the reestablishment of native riparian vegetation compared to IAS within an ecological river restoration project.

While anthropogenic disturbances can introduce non-native species to riparian habitats, subsequent natural disturbances can facilitate the further spread of such IAS [17], and changed river flows can provide advantageous conditions for invasive species. Since restoration projects can be viewed as disturbances, it appears essential to evaluate their possible negative effects [18].

Previous research has focused on the impact of IAS in established riparian areas [6]. There has been little focus on the influence of IAS on newly created river channels [19] [20]. Especially the seed bank of IAS is considered to be a limiting factor for achieving the goals of river restoration programs [21]. The aim of this study is to present observations of IAS development before the construction of a new river bed as well as observations of the vegetation development of the initial vegetation cover and seed bank along newly created river banks within the first two years following the creation of a new river channel.

First, we asked whether native target plant species colonize and spread in sites after the restoration where they were not planted. Second, we measured whether invasive plant species colonize and spread in sites, thereby influencing the successional process of the native riparian vegetation of the study area. Third, we ask whether the occurrence of seeds of IAS in the soil seed bank is correlating with the aboveground vegetation. We focus on the before and after occurrence within the first year of distribution, using most recent data. The authors thereby hope to contribute important information for future river restoration projects.

\section{Material and Methods}

\subsection{Study Area}

The research area is located along the river Danube and the downstream section of the river Traisen in Lower Austria. In the 19th century, the river was regulated to reduce the number of floods and increase the land area available for cultivation. When the Danube hydroelectric power plant in Altenwörth was built in the 1970s, the outfall of the river Traisen was relocated [22] [23]. The current vegetation around the river Traisen is characterized by different intensities of forest cultivation and anthropogenic influences which occurred during the past two centuries. The typical relationship between the ecosystems river-bank-backlands—-wetland water bodies was largely destroyed, and the reduction of the natural disturbance of flood regimes affected the species composition. Side channels of the river were cut off and slowly dried up, and due to the reduced flooding cycle, oak/ elm/ash forests now dominate the area [22]. The typical pioneer vegetation is preserved only in small regions within the area [22], and only minor fragments of the typical softwood riparian forests remain [15]. Despite the negative influence which the relocation had on the ecological situation, the biodiversity remains high, and therefore the floodplains around Zwentendorf were incorporated into the network of Natura 2000 sites. Since 2004, the area has been part of the Natura 2000 site "Tullnerfelder Donau-Auen" with a total area of 17.990 ha [23] [24], in which the largest connected alluvial forests in Austria can be found.

\subsection{Restoration Project LIFE+ Traisen}

The section of the river Traisen between Traismauer and Zwentendorf is to be replenished with a vital alluvial 
landscape. After years of considering improvements to the ecological situation of the river Traisen, scientists and technicians began with the idea of creating a new river bed in 2005. This new river bed does not follow the historical course of the river, a fact that makes the LIFE+ Traisen project unique. The intention was to link the new river with the wetlands, restore fish accessibility and offer diverse habitats. The design of the LIFE+ Traisen project follows specifications of the European Water Framework Directive [25] and contributes significantly to the improvement of the Natura 2000 area by improving the hydro-ecological conditions and creating natural riparian habitats with characteristic vegetation structures. Its main goals are the reshaping of the lower course of the Traisen into an ecologically valuable and functioning river landscape according to the EU Water Framework Directive on the one hand, and the development of habitats according to the Habitats Directive on the other. Top priority is assigned to the development of around 80 ha of "softwood riparian forest" (Habitat type 91E0*) through natural flooding by the new meandering course of the river Traisen (Figure 1).

\subsection{Target Plant Communities for Habitat Type 91E0*}

One of the primary goals of the Life+ Traisen project is the development of an intact softwood riparian forest of habitat type 91E0* (Alluvial forests with Alnus glutinosa and Fraxinus excelsior) — a priority habitat type as per the Habitats Directive-along the banks of the new course of the Traisen [26] [27]. This habitat type embraces alder and ash riparian forests along waterways as well as (in part) forests containing springs and streams in valleys and slope toes. Their common feature is the conditions created by periodic flooding. The following species

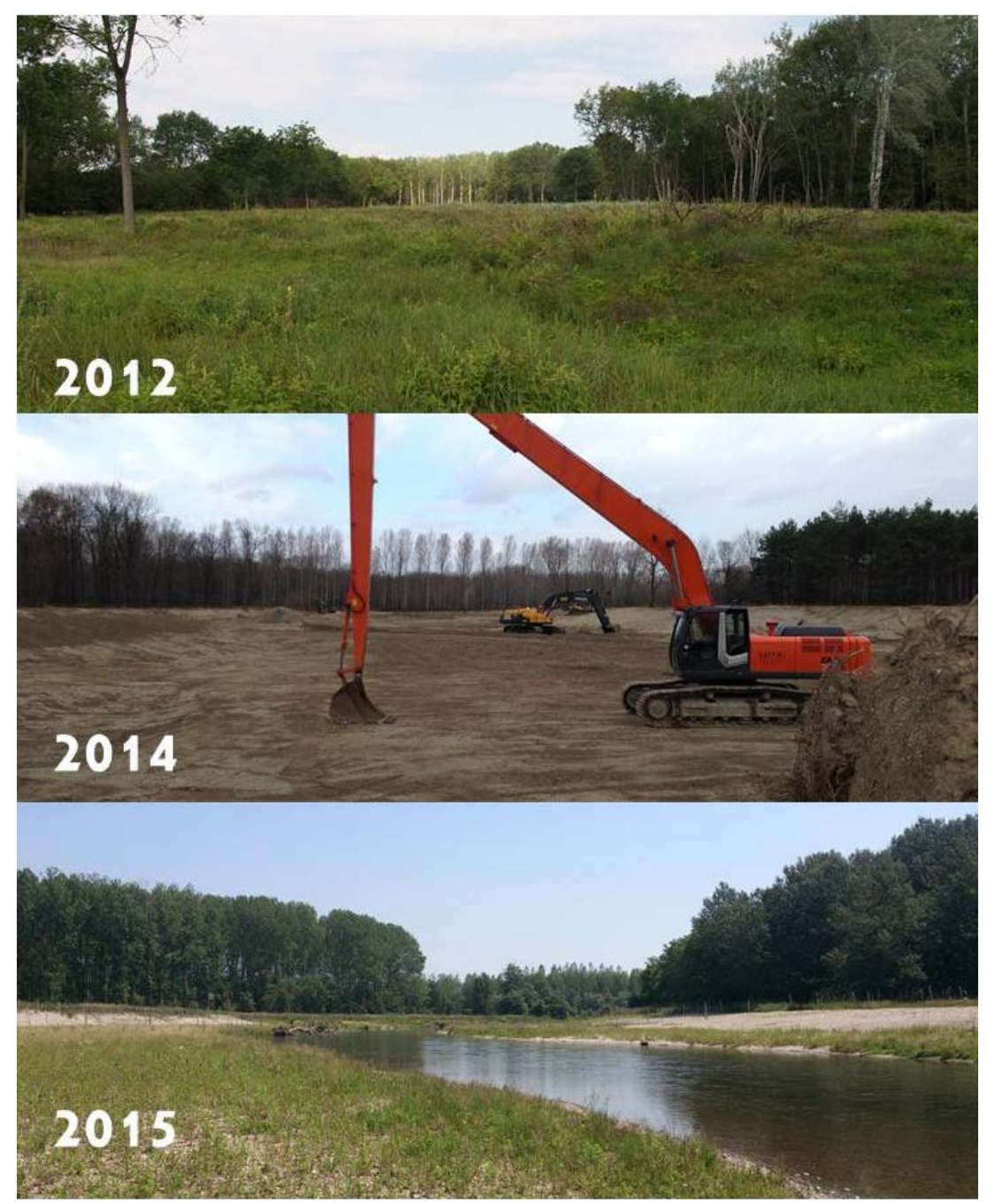

Figure 1. Construction section No.1 over the course of work in 2012, 2014 und 2015. 
are characteristic for the habitat type 91E0* and therefore defined as target species for the study: Alnus glutinosa, Alnus incana, Fraxinus excelsior, Salix alba, Salix fragilis, Populus nigra, Prunus padus, Ribes rubrum, Humulus lupulus, Stellaria nemorum, Carex strigosa, Carex remota, Cardamine amara, Carex pendula, Angelica sylvestris, Cirsium oleraceum, Equisetum telmateia, Lysimachia nemorum, Chrysosplenium alternifolium [26] [28].

\subsection{Invasive Alien Plants in the Area}

In total, there are eight different vascular plant species previously detected and classified as invasive alien plant species [15] [23]. According to Essl and Rabitsch [29], these eight IAS are well established and can be found in every province of Austria: Ailanthus altissima, Acer negundo, Bunias orientalis, Robinia pseudoacacia, Rudbeckia lancinilata, Impatiens glandulifera, Impatiens parviflora and Solidago gigantea [30]-[33].

\subsection{Aboveground Vegetation Sampling}

The study area is located between $\mathrm{N} 48^{\circ} 22^{\prime} 12.5^{\prime \prime} / \mathrm{E} 15^{\circ} 48^{\prime} 07.1^{\prime \prime}$ and $\mathrm{N} 48^{\circ} 21^{\prime} 40.4^{\prime \prime} / \mathrm{E} 15^{\circ} 52^{\prime} 47.8^{\prime \prime}$ were sampled. Recording of the vegetation cover occurred ( $\mathrm{n}=40$ plots) was provided in 2012 prior to the beginning of construction work on the new river course, in 2014 in the first vegetation period after completion of the new course, and in 2015 in the second year following completion. The recording areas were located along transects arranged perpendicular to the center line of the new Traisen river bed (Figure 2). At each measuring point $(n=40)$ a 200 $\mathrm{m}^{2}(10 \mathrm{~m} \times 20 \mathrm{~m})$ recording area was laid out. The vegetation cover-abundance was estimated using the BraunBlanquet scale [34], differentiated into the herbal layer (0 to $1 \mathrm{~m}$ ), shrub layer (1 to $5 \mathrm{~m}$ ), tree layer 1 (5 to $10 \mathrm{~m}$ ), and tree layer 2 (10 to $20 \mathrm{~m}$ ). The nomenclature of the flora is in accordance with Adler et al. 2008 [35].

\subsection{Seed Bank Analysis}

In order to determine the spreading potential of invasive alien plants, a seed bank analysis was conducted [36]. In autumn 2011 (prior to the start of construction work), in spring 2014 (immediately after completion of the work) and in 2015 (in the second year after completion), ten soil samples were taken from each recording area (total: $\mathrm{n}=400$ ). Each sample was taken down to a depth of $20 \mathrm{~cm}$ (with a diameter of $5.6 \mathrm{~cm}$ ). The following depth regions were differentiated in order to analyze the occurrence of seeds at different depths: 0 to $5 \mathrm{~cm}, 5$ to $10 \mathrm{~cm}$, and 10 to $20 \mathrm{~cm}$ [37]. After being flushed through testing sieves, the samples were searched for seeds [38]. The seed collection at the Institute of Botany at the University of Natural Resources and Life Sciences was used to find and identify the seeds. As the similarity between certain seeds made definitive identification impossible in some cases, those seeds were planted in the University's unheated greenhouse to determine their species. To prevent mistakes, eight " 0 -samples" containing only substrate were set up along with the specimens in question [37]. The samples were watered regularly and their growth monitored for 6 weeks, after which the species could be determined. A conversion factor was then used to estimate the number of seeds per $\mathrm{m}^{2}$ of each of the identified species [38].

\subsection{Data Analysis}

The resulting data were first tested for normal distribution and transformed [39]. To determine the differences between the series under consideration of the parameters, a Mann-Whitley-Wilcoxon test was conducted [40] [41]. The relationships between number of species, dominance and abundance were determined via Pearson Product-Moment Correlation. To prove the significance of the relationship between the change of the mean percentage of the aboveground vegetation coverage from the study years and density of seeds of invasive alien plants in the seed bank, a Fischer's exact test was performed [42]. We also tested for a relationship between seed occurrence and the coverage in the herb layer with $2 \times 2$ contingency tables, and used Fisher's exact tests when too many cell frequencies were $<5$ because of the low number of values. Statistical analysis of the data was conducted using the computer program "R (32-bit)" (R Core Team 2012).

\section{Results}

\subsection{Above-Ground Vegetation}

None of the invasive species in the seed bank has a normal distribution over the study area in 2011 and 2014, 
2015 (Shapiro-Wilk test, p > 0. 05). In the year 2012, 205 plant species were found in the study area. Of these species, 9 were among the abovementioned invasive species and 8 among the abovementioned target species (Table 1). The abundance of IAS was significantly higher than the abundance of target species (Pearson Correlation, p $<0.05$ ). Salvia glutinosa was the most frequent species. Solidago gigantea was found in 40 plots and covered $14.88 \%$ of the total area. Likewise appearing in 40 plots, Impatiens parviflora covered $7.64 \%$ of the total area. Impatiens glandulifera occurred in 15 plots and covered 3.55\% of the total area. Appearing in 11 plots, Robinia pseudoacacia covered $0.39 \%$ of the total area. Ailanthus altissima was discovered in 6 plots and covered $0.04 \%$ of the total area. Covering $0.04 \%$ of the total area, Bunias orientalis appeared in 4 plots, while Acer negundo was found in 4 plots and covered $0.04 \%$ of the total area. Rudbeckia lanciniata occurred in 3 plots and covered $0.83 \%$ of the total area. Finally, Fallopia japonica covered $0.03 \%$ of the total area and was discovered in 1 plot (Table 1).

In 2012 in total 8 target species were discovered (Table 1). Fraxinus excelsior appeared in 30 plots and covered $0.51 \%$ of the total area. Discovered in 19 plots, Alnus incana covered $1.55 \%$ of the total area. Humulus lupulus was found in 3 plots and covered $0.05 \%$ of the total area. Prunus padus appeared in 3 plots and covered $0.04 \%$ of the total area, while Salix alba covered $0.07 \%$ of the total area and was likewise found in 3 plots. Alnus glutinosa occurred in 2 plots and covered $0.02 \%$ of the total area. Populus nigra also appeared in 2 plots and covered $0.46 \%$ of the total area. Cirsium olearaceum covered $0.01 \%$ of the total area and occurred in 1 plot (Table 1).

In the year 2014, the number of species discovered was 76, with 5 of these among the invasive species and

Table 1. Average cover (Cov", \%) of IAS and target species and number of invaded plots $\left(\mathrm{n}^{* *}\right)$ in the years 2012, 2014 and $2015(\mathrm{n}=40)$.

\begin{tabular}{|c|c|c|c|c|c|c|}
\hline & \multicolumn{2}{|c|}{2012} & \multicolumn{2}{|c|}{2014} & \multicolumn{2}{|c|}{2015} \\
\hline Species number (total) & \multicolumn{2}{|c|}{205} & \multicolumn{2}{|c|}{76} & \multicolumn{2}{|c|}{215} \\
\hline Av. plant cover [\%] & \multicolumn{2}{|c|}{69.58} & \multicolumn{2}{|c|}{96.65} & \multicolumn{2}{|c|}{83.66} \\
\hline Av. cover of IAS [\%] & \multicolumn{2}{|c|}{27.71} & \multicolumn{2}{|c|}{2.97} & \multicolumn{2}{|c|}{3.77} \\
\hline \multirow[t]{2}{*}{ Cover of target species [\%] } & \multicolumn{2}{|c|}{2.7} & \multicolumn{2}{|c|}{0.38} & \multicolumn{2}{|c|}{12.57} \\
\hline & $\operatorname{Cov}^{*}$ & $\mathrm{n}^{* *}$ & $\operatorname{Cov}^{*}$ & $\mathrm{n}^{* *}$ & $\operatorname{Cov}^{*}$ & $\mathrm{n}^{* *}$ \\
\hline \multicolumn{7}{|l|}{ Invasive alien plant species } \\
\hline Acer negundo & 0.04 & 4 & 0.55 & 9 & 0.28 & 16 \\
\hline Ailanthus altissima & 0.04 & 6 & 0.11 & 2 & 0.06 & 10 \\
\hline Bunias orientalis & 0.31 & 4 & 0 & 0 & 0.32 & 7 \\
\hline Fallopia japonica & 0.03 & 1 & 0 & 0 & 0 & 0 \\
\hline Impatiens glandulifera & 3.55 & 15 & 0 & 0 & 0.33 & 8 \\
\hline Impatiens parviflora & 7.64 & 40 & 1.98 & 11 & 0.26 & 5 \\
\hline Robinia pseudoacacia & 0.39 & 11 & 0.22 & 4 & 0.35 & 16 \\
\hline Rudbeckia laciniata & 0.83 & 3 & 0 & 0 & 0 & 0 \\
\hline Solidago gigantea & 14.88 & 40 & 0.11 & 2 & 2.14 & 40 \\
\hline \multicolumn{7}{|l|}{ Target species } \\
\hline Alnus glutinosa & 0.02 & 2 & 0 & 0 & 0 & 0 \\
\hline Alnus incana & 1.55 & 19 & 0.38 & 6 & 0.05 & 5 \\
\hline Cardamine amara & 0 & 0 & 0 & 0 & 0.02 & 2 \\
\hline Cirsium oleraceum & 0.01 & 1 & 0 & 0 & 0.01 & 1 \\
\hline Fraxinus excelsior & 0.51 & 30 & 0 & 0 & 0.13 & 6 \\
\hline Humulus lupulus & 0.05 & 3 & 0 & 0 & 0 & 0 \\
\hline Populus nigra & 0.46 & 2 & 0 & 0 & 10.96 & 40 \\
\hline Prunus padus & 0.04 & 3 & 0 & 0 & 0.07 & 2 \\
\hline Salix alba & 0.07 & 3 & 0 & 0 & 0.94 & 19 \\
\hline
\end{tabular}


only 1 among the target species. The most frequent species within the study area in 2014 over all was Echinochloa crus-galli, which occurred in 28 of 40 plots. This was followed by Eupatorium cannabinum in 22 plots and Persicariamayor in 21 plots. Eupatorium cannabinum was found with a high occurrence in all three study years (2012, 2014 and 2015). The 5 invasive species were discovered in 2014 (Table 1). It is noteworthy that Ailanthus altissima only established itself in June 2014, and that Solidago gigantea was limited to the same two plots in August 2014 in which it had already occurred in May 2014. Impatiens parviflora appeared in 11 examined plots and covered $1.98 \%$ of the total area. Occurring in 9 plots, Acer negundo covered $0.55 \%$ of the total area. Robinia pseudoacacia was found in 4 plots and covered $0.22 \%$ of the total area. Ailanthus altissima covered $0.11 \%$ of the total area and occurred in 2 plots (Table 1 ). The only one of the 19 target species found in 2014 was Alnus incana, which appeared in 6 plots and covered $0.38 \%$ of the total area.

In the year 2015 in total of 215 species were found, with 7 of these among the invasive species and 7 among the target species (Table 1). The abundance of target species was significantly higher than the abundance of IAS (Pearson Correlation, p < 0.05). The most frequent species in 2015 was Plantago major. Occurring in 40 plots, Solidago gigantea covered $2.14 \%$ of the total area. Acer negundo was found in 16 plots and covered $0.28 \%$ of the total area. Robinia pseudoacacia appeared in 16 plots and covered $0.35 \%$ of the total area. 10 plots were inhabited by Ailanthus altissima, which covered $0.06 \%$ of the total area. Impatiens glandulifera was discovered in 8 plots and covered $0.33 \%$ of the total area, while Bunias orientalis appeared in 5 plots and covered $0.32 \%$ of the total area. Finally, Impatiens parviflora covered $0.26 \%$ of the total area and occurred in 5 plots (Table 1 ). In 2015 in total 7 target species were discovered (Table 1). Appearing in 40 plots, Populus nigra covered 11.25\% of the total area. Salix alba covered $1.02 \%$ of the total area and occurred in 19 plots, while Fraxinus excelsior was found in 6 plots and covered $0.13 \%$ of the total area. Alnus incana inhabited 5 plots and covered $0.05 \%$ of the total area. Cardamine amara covered $0.02 \%$ of the total area and occurred in 2 plots. Discovered in 2 plots, Prunus padus covered $0.08 \%$ of the total area. Lastly, Cirsium oleraceum covered $0.01 \%$ of the total area and appeared in 1 plot (Table 1).

\subsection{Seed Bank Analysis}

During the first examination in the year 2011, a large number of invasive alien plants were discovered on the surface as well as in the soil in the shape of diaspores. Solidago gigantea showed the highest number of individual seeds as well as the greatest abundance at 262.8 seeds per $\mathrm{m}^{2} .163$ individual seeds, or 97.8 seeds per $\mathrm{m}^{2}$, of Impatiens glandulifera, the second most abundant invasive species, were found. The third greatest number of seeds belonged to Impatiens parviflora, with 82 individual seeds or 49.2 seeds per $\mathrm{m}^{2}$. Bunias orientalis showed the lowest abundance with 34 individual seeds or 20.4 seeds per $\mathrm{m}^{2}$. During the following examination in 2014, far fewer IAS seeds were found in the diaspore bank. Only 16 (19.2 seeds per $\left.\mathrm{m}^{2}\right)$ seeds of Impatiens glandulifera, 6 (7.2 seeds per $\left.\mathrm{m}^{2}\right)$ seeds of Impatiens parviflora, and $5\left(6\right.$ seeds per $\left.\mathrm{m}^{2}\right)$ seeds of Bunias orientalis were discovered, while not a single seed of Solidago gigantea was found. In the year 2015, the number of invasive alien plants in the diaspora bank was 0.00 . No seeds of any invasive alien species were found within the study area. Of the designated target species, only Alnus incana could be verified in the vegetation samples from the surface in 2014. In the 2015 diaspore bank analysis, 4 individual seeds (4.8 seeds per $\mathrm{m}^{2}$ ) of Alnus incana were discovered. The most frequently found seeds in 2015 were those of Setaria pumila $\left(\mathrm{n}=131,157.2\right.$ seeds per $\left.\mathrm{m}^{2}\right)$ and Echinochloa crus-galli $\left(\mathrm{n}=77,92.4\right.$ seeds per $\left.\mathrm{m}^{2}\right)$. Other frequently occurring seeds were those of Persicariadubia $\left(\mathrm{n}=22,26.4\right.$ seeds per $\left.\mathrm{m}^{2}\right)$. Furthermore, seeds of 3 target species were found: Alnus incana $(\mathrm{n}=4,4.8$ seeds per $\left.\mathrm{m}^{2}\right)$, Humulus lupulus $\left(\mathrm{n}=1,1.2\right.$ seeds per $\left.\mathrm{m}^{2}\right)$ and Prunus padus $\left(\mathrm{n}=1,1.2\right.$ seeds per $\left.\mathrm{m}^{2}\right)$. In the year 2011/2012, the greatest number of IAS seeds $(n=499)$ were discovered in the topmost soil layer examined $(0$ $5 \mathrm{~cm}$ ). 157 seeds were found at depths of $5-10 \mathrm{~cm}$, and 61 seeds at depths of $10-20 \mathrm{~cm}$. In the course of the 2014 examination, the soil layer between 10 and $20 \mathrm{~cm}$ was found to contain the greatest number of IAS seeds $(\mathrm{n}=15)$. The layers $0-5 \mathrm{~cm}$ and $5-10 \mathrm{~cm}$ contained only 6 seeds each. In the year 2015, no seeds of any invasive alien plant species were found in the soil samples. The distribution of seeds within the different construction measures and layers showed no normal distribution over the various construction areas in 2014 and 2015 (Shapiro-Wilk test, $\mathrm{p}>0.05$ ). In 2014, the greatest number of IAS seeds was discovered in the HQ1 river bed areas (Figure 2). In these areas, Impatiens glandulifera was the most abundant $\left(\mathrm{n}=13.2\right.$ seeds per $\left.\mathrm{m}^{2}\right)$. IAS seeds were also found in the buffer zone areas (Figure 2), with Impatiens glandulifera again being the most frequent ( $\mathrm{n}=6$ seeds per $\mathrm{m}^{2}$ ). In the lowered areas (Figure 2) surrounding the river bed, however, only seeds of 


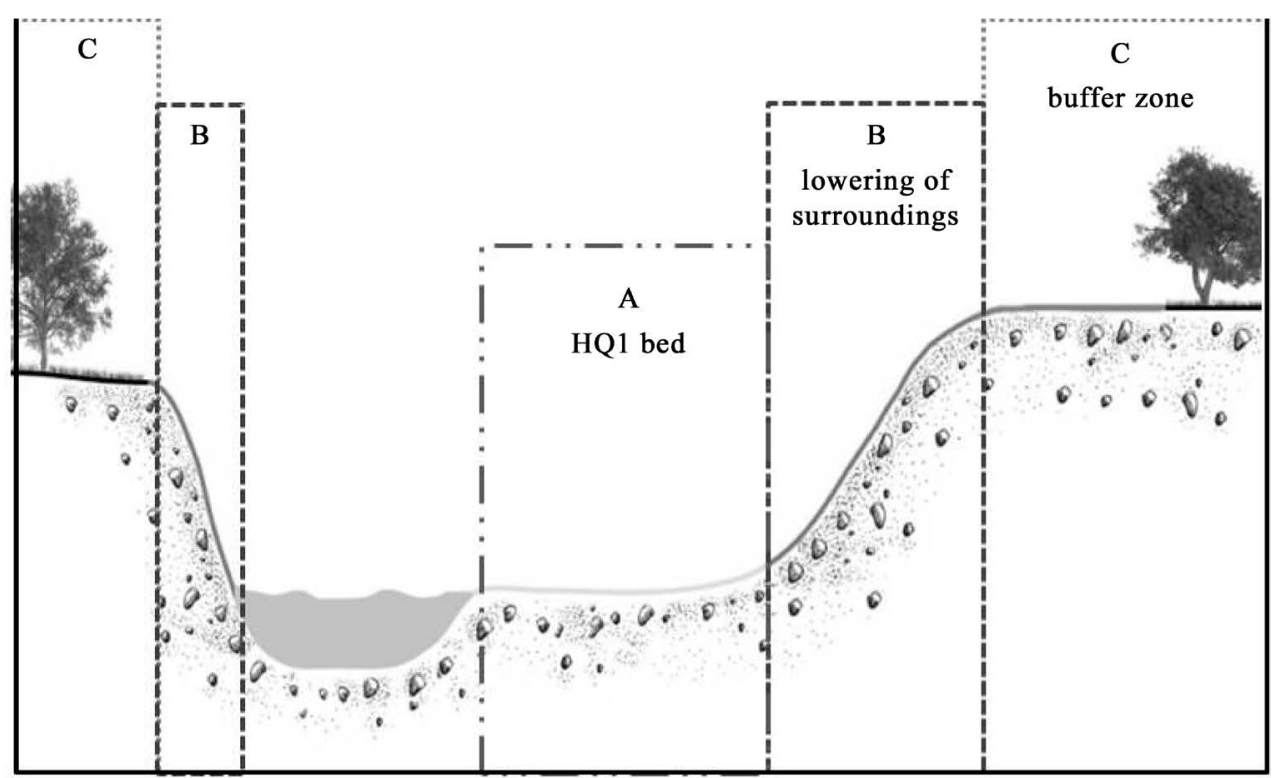

Figure 2. Scheme of transects with different construction measures along the new river bed of the river Traisen within the LIFE+ Project: A-HQ1 bed, B-lowering of surroundings, and C_-buffer zone.

Bunias orientalis were discovered $\left(n=2.4\right.$ seeds per $\mathrm{m}^{2}$ ). In the year 2015 , no seeds of invasive alien plant species were found.

\subsection{Comparison of the Soil Seed Bank Analysis with the Above-Ground Vegetation}

In 2011, the results showed the presence of seeds of invasive species in the soil seed bank. The spread of invasive alien plants sampled above ground into non-invaded areas was not related to their occurrence in the seed bank, however. The performed Fischer's exact test showed no significant relation between the detected seed occurrence and the increase or decrease of coverage by invasive alien plant species in the herb layer from the year 2011 to 2012 ( $p=0.247$ ). In the course of the diaspore bank examination in the year 2015, no seeds of invasive alien plants were found in the soil. After completion of the construction work in 2015, not all species whose seeds were discovered in the soil were also to be found growing on the surface. Alnus incana, Echinochloa crus-galli, Glechoma hederacea, Persicaria sp., Prunus padus, Rumex obtusifolius, Salvia glutinosa and Setaria pumila were present as diaspores in the soil as well as on the surface. Seeds of the species Carexacutiformis, Carex riparia, Chenopodium album, Humulus lupulus, Panicum miliaceum, Sambucus nigra, Sparganium erectum and Viola riviniana were found in the soil, but no representatives of these species occurred on the surface. Furthermore, although no invasive alien plant seeds were found in the soil in 2015, individuals of several such species were discovered on the surface. Solidago gigantea was the most abundant in the vegetation sampling, appearing in 20 of the examined plots. Impatiens glandulifera occurred in 7 plots and Impatiens parviflora on none of the plots, while Bunias orientalis was found in 5 plots.

\section{Discussion}

\subsection{Influence of IAS on Succession}

The restoration efforts of the LIFE + Traisen project followed a traditional successional trajectory, where the re-establishment of abiotic conditions promote the natural vegetation recovery. According to this succession model the re-establishment was successful. In the case of the LIFE+ Traisen project the re-establishment of native riparian species was successful in short-terms. Long-term changes need to be monitored. Further the riparian vegetation of European rivers is seldom completely free of IAS [30] [43] [44]. Accordingly, the riparian vegetation of the renatured Traisen river is likewise not entirely free of invasive alien plants. The average IAS cover abundance in the Traisen riparian areas was significantly lower after the renaturation work than before. This result matches similar observations from other Central European river renaturation efforts [44]. However, 
the IAS cover abundance around the recently renatured Traisen is much lower than it is in comparable projects. It will therefore be important to continue to closely observe the development of the pioneer vegetation in the coming years in order to evaluate the effect of the measures taken in the LIFE+ Traisen project, and to eventually use it as a reference project. The future development of the competitive behavior of the invasive species versus the native pioneer species, especially in a dynamic river system like the one created by the LIFE+ Traisen project is unpredictable [45] [46].

The success of reestablishment of native pioneer species was not limited by the occurrence of IAS. Within the examined section of the river system, the pioneer species Plantago major, Conyza canadensis, Eupatorium cannabium, Echinochloa crus-galli, Mentha longifolia, Erigeron annuus, Cirsium arvense, Hypericum perforatum, Leontodon sp. Persicaria sp. and Populus sp. established themselves most quickly. The invasive species Solidago gigantea was among the 15 most dominant species. Target species of the priority habitat "soft wood riparian forest" (91E0*) like Alnus incana, Salix alba, und Populus nigra appeared via Wind dispersal within the first months of 2014 after completion of the earth-moving work, in particular in bankside areas with coarse gravel (>300 mm). In the year 2015, cuttings of the target species Alnus incana, Fraxinus excelsior, Populus nigra and Salix alba, as well as of Populus alba, a non-designated target species, were planted. The cover percentage of IAS in areas planted with target species is below $0.01 \%$ and thus significantly lower than the cover percentage of IAS in areas not planted with cuttings (0.03\%). As shown in previous studies on the topic [15] [47], IAS are not necessarily more competitive than the target species. The situation is different, however, in areas where there is a finer sediment and no target species cuttings were planted. In these areas, the average cover abundance of IAS was $0.03 \%$ higher than in the areas where the target species were given a competitive advantage. As a result, the authors recommend measures to promote native target species, like the planting of cuttings, for future river renaturation projects.

The invasive herbaceous perennial Solidago gigantea formed thick-cover populations throughout the entire study area prior to the commencement of construction work. In August 2014, only a single individual was found in each of two transects, but in 2015, the second year following completion of the work, Solidago gigantea was already discovered in all transects. As this species is particularly competitive and forms pure stands [48], it is important to closely monitor its development in the examined areas. Controlling Solidago gigantea over large areas is difficult due to the species' excellent dispersal strategy. The not regularly flooded areas in particular, like the HQ 1 bed, should be examined regularly and subjected to active monitoring.

\subsection{Role of the Seed Bank}

Any event that produces a change in ecosystem structure and resource availability is defined as a disturbance. Disturbances are often an important driver of ecosystem dynamics, are therefore an important feature of ecosystems themselves, and also provide opportunities for regeneration [7]. Although the disturbance along the river Traisen caused by the renaturation project seems to have had a positive impact on the abundance of invasive seeds in the ground (Figure 3), disturbances are generally regarded to facilitate biological invasions, particularly in regard to plants [6]. After a disturbance, species with rapid germination, rapid initial growth and an efficient dispersal mechanism are most likely to (re-)establish populations within the disturbed area. Disturbances do not always lead to invasions, however, the outcome is dependent on local conditions and the availability of diaspores of invasive species [49]. In riparian zones, anthropogenic disturbances may introduce non-native species, but natural disturbances may facilitate their further spread [17], while altered river courses may provide advantageous conditions for invasive species [49]. Furthermore, despite the positive effects the restoration project of the river Traisen may have in the future, it must be kept in mind that restoration can also be viewed as a disturbance event [50] —in the case of the LIFE+ Traisen project, the preparatory work in particular, such as clearing forest areas, already had a significant impact [15]. Further germinable seeds in the soil are very important for the regeneration and/or establishment of plant populations [51], and some species even create persistent seed banks. These seed banks can be used to predict the species composition of new plant regimes [52]. Analysis of the soil seed bank was not used for predictions concerning the study area, however. Rather, the analysis in this study was used in order to recognize dangers early on and prevent the displacement of seeds of invasive alien species. This utilization of information from the seed bank has proven useful and is therefore also recommended for future river renaturation projects. Prior to the start of construction work in 2012, the soil was examined for the incidence of IAS. The seed bank survey conducted in 2011 was not able to convincingly prove that the occurrence 
of diaspores in the soil was directly related to the occurrence of invasive alien plants in the herb layer. Such a connection could also not be excluded, however, as further investigation was required to answer the question whether diaspores in the soil are responsible for the occurrence of IAS on the surface. The large number of diaspores of invasive species nevertheless did inspire sensitive handling of the topsoil, resulting in the contaminated topsoil from the area of lowered surroundings not being reused directly, but instead being transferred to the HQ1 bed, where the high dynamics of yearly flooding events promotes the target species while suppressing the spread of IAS [44]. This measure impeded the spread of IAS in the sensitive first phases after the construction work in which the settling of native pioneer species was desired. Alien plants that had managed to establish their presence by 2015 are to be attributed to deposition by water or wind [53]. The examination of the seed bank by depth emphasizes this result. One possible reason for no IAS seeds being found in 2015 may be a spring flooding event in 2015 which influenced the seed bank dynamic for 2015. There is a further significant difference between the results from 2012 and 2014 (Figure 3): In 2012, significant less seeds per $\mathrm{m}^{2}$ were found in the topmost soil layer, than in the middle layer and in the bottommost layer. This indicates a strong effect attributable to the earthmoving work within the construction site. What had previously been the topmost soil layer was buried and moved to greater depths, causing most of the invasive seeds to be found in the bottommost layer. The earthmoving also explains why most of the invasive seeds were found in the HQ1 bed area after the construction work: large amounts of earth had been pushed from the "lowered surroundings" area to the HQ1 bed area. In this latter area, invasive species are not as problematic as in the "lowered surroundings" area, since the area is flooded once per year, thus restricting the establishment of invasive and non-flooding-resistant species. It must be kept in mind, however, that these regular flooding events also result in greater seed dispersal via the waterway. Further it needs to be considered, that IAS ten to dominate the seed bank when the degradation of the riparian vegetation increases [21]. The results of this study support that the seed bank needs to be implemented in the goals of river restoration programs.

\subsection{Action Recommendations}

In many countries, the number of river renaturation projects has risen significantly in the past years [54]-[56]. Within the EU, these efforts are driven in particular by the EU Water Framework Directive [25]. Although the goal of such renaturation projects is the improvement of the ecological state of river environments, it must be kept in mind that they generally include large-scale construction work which always constitutes a massive

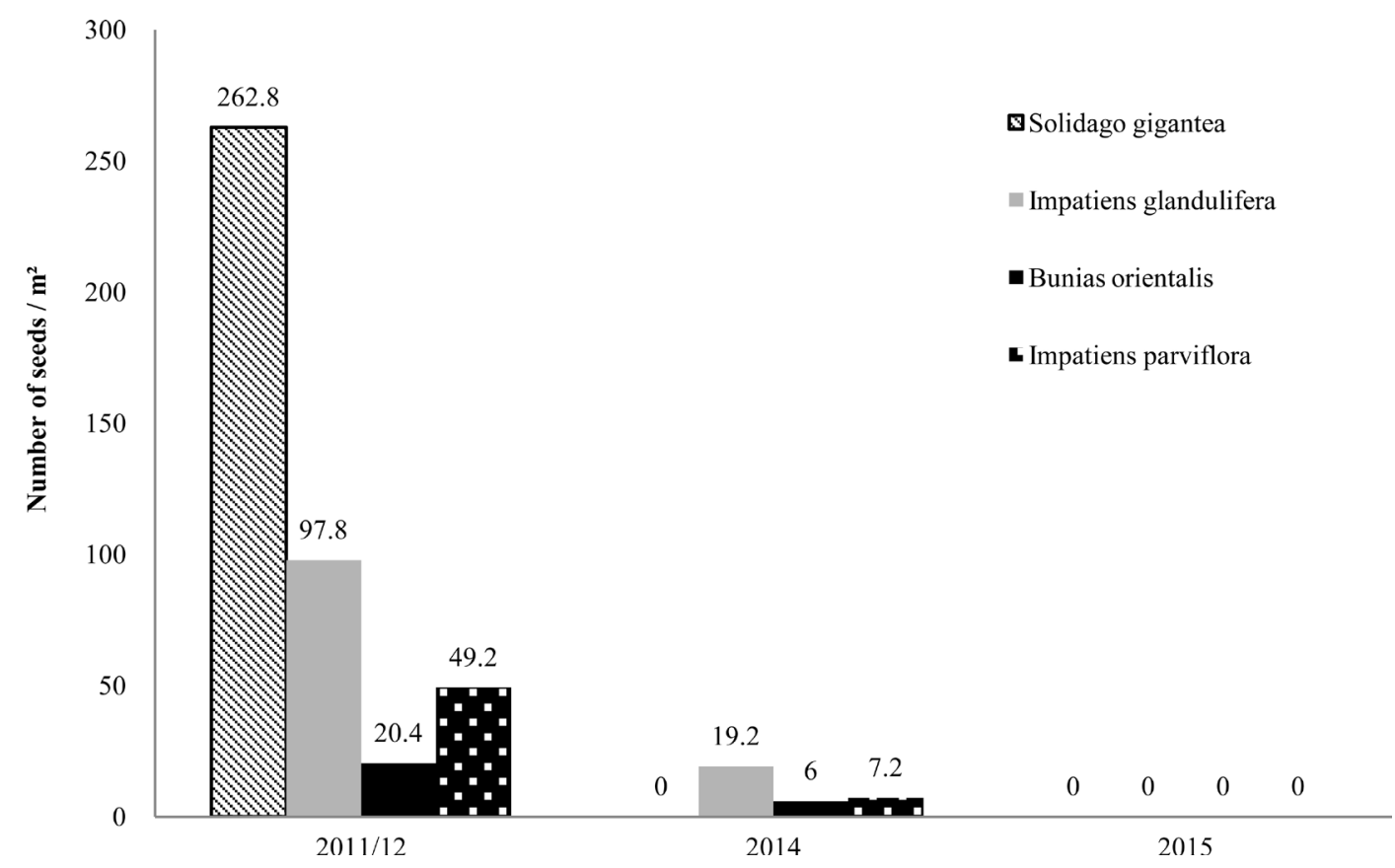

Figure 3. Average number of seeds per $\mathrm{m}^{2}(\mathrm{n}=400$ samples) of invasive species Solidago gigantea, Impatiens glandulifera, Bunias orientalis and Impatiens parviflora in 2011, 2014 and 2015. 
anthropogenic disturbance to the area - even when its ultimate purpose is the promotion of natural parameters [57]. And any anthropogenic disturbance is likely to promote the spread of IAS. This should not be taken to mean that river renaturation efforts should no longer be undertaken in future; however, sufficient attention should be paid to the management of IAS from the very beginning of such projects [44]. For the success of ecological river restorations, the re-establishment of riparian vegetation is essential.

Haag and Krüsi (2013) [44], who compared restored and unrestored sections of 16 rivers in Switzerland between 2011 and 2012, found that alien plants spread in great numbers once they are established. Furthermore, their findings imply that recently restored sites contained more alien plants than sites restored six or more years previously. This means that succession is the main influence causing the diversity of alien plants to decline over time. Additionally, newly restored rivers are most prone to attracting alien plants from surrounding areas. Hence river dynamics, for example frequent flooding events, are important for fostering native plants and reducing invasions. There is, however, also the unfortunate possibility that diversity does not increase at restored sites [58].

The data of this study shows an advantage for the native pioneer species in the first two years following construction work. In 2012, $27.71 \%$ of the study area was covered by invasive species, while only $2.70 \%$ was covered by target species. In the 2014 investigations, shortly after the completion of construction work, $2.97 \%$ of the area was covered by invasive species and $0.38 \%$ by target species. In 2015, however, the cover percentage of invasive species was $3.55 \%$ and that of designated target species was $12.19 \%$ of the total study area. This success can be attributed to a large degree to the precautionary examination of the seed bank as well as the expeditious promotion of the target species through the planting of cuttings immediately following the construction work. Increasing awareness of the IAS problem resulted in a constructive channeling of the IAS distribution within the LIFE+ Traisen project. The occurrence of diaspores of invasive species is of great importance for the positive development of native riparian vegetation. As was done in the LIFE+ Traisen project, planning should include measures to ensure that seeds of invasive species are not unnecessarily dispersed in the course of earthmoving work.

The results of this study show that promotion of the desired target species can counteract the spread of IAS. In a properly formed softwood riparian forest environment, IAS is insufficiently competitive in comparison with native species. The transects should be replanted with suitable vegetation as soon as possible to prevent the spread of invasive species, as intact natural vegetation impedes the establishment and spread of IAS [57]. The success of river renaturations is primarily dependent on the succession process in the 10 years following conclusion of construction work. In appropriate long-term data series, the authors expect to see whether IAS is a temporary or permanent problem [44]. The measures conducted along the Traisen can currently be viewed as satisfactory in regard to the spread of IAS, as the natural competitiveness of native target species was initially promoted. It must be emphasized, however, that long-term success can ultimately only be achieved through active monitoring continuing up to the successful establishment of softwood riparian forests as defined in habitat type 91E0*.

Handling invasive species is difficult and is often a controversial issue. Besides the preserving nature conservation management approach, where non-native species are generally seen as a negative influence, there also exists a dynamic approach which accepts changes in nature as a natural part of ecosystems [30]. A purely dynamic approach, however, would lead to a loss of species and their compositions which rely on original or historic habitats. On the other hand, when concentrating too much on the preservation of the original conditions, adjustment processes might be missed. Therefore a combination of both approaches is recommended to balance out their respective disadvantages [30]. The LIFE+ Traisen project is an excellent example of the fact that habitat loss and the invasion of non-native environments have points of intersection and cannot be completely separated from each other. Invasive alien plants prefer to spread in disturbed areas. Restoration and permanent support of such areas, as well as the protection of intact natural habitats, promote the competitiveness of native species and reduce the danger of establishment of invasive alien species.

\section{Acknowledgements}

This project would not have been possible without the support of all co-authors by the Institute of Botany. The University of Natural Resources and Life Sciences is acknowledged for providing the authors with access and its resources. The financial support from the VERBUND AG trough the LIFE+ Traisen project is likewise gratefully acknowledged. Finally, we would like to thank Stephan Stockinger, whose comments on the English language and style helped to improve this paper. 


\section{References}

[1] Morandi, B., Piégay, H., Lamouroux, N. and Vaudor, L. (2014) How Is Success or Failure in River Restoration Projects Evaluated? Feedback from French Restoration Projects. Journal of Environmental Management, 137, 178-188. http://dx.doi.org/10.1016/j.jenvman.2014.02.010

[2] Wohl, E., Lane, S.N. and Wilcox, A.C. (2015) The Science and Practice of River Restoration. Water Resources Research, 51, 5974-5997. http://dx.doi.org/10.1002/2014WR016874

[3] Gillilan, S., Boyd, K., Hoitsma, T. and Kauffman, M. (2005) Challenges in Developing and Implementing Ecological Standards for Geomorphic River Restoration Projects: A Practitioner's Response to Palmer et al. (2005). Journal of Applied Ecology, 42, 223-227. http://dx.doi.org/10.1111/j.1365-2664.2005.01021.X

[4] Palmer, M.A., Bernhardt, E.S., Allan, J.D., Lake, P.S., Alexander, G., Brooks, S. and Galat, D.L. (2005) Standards for Ecologically Successful River Restoration. Journal of Applied Ecology, 42, 208-217. http://dx.doi.org/10.1111/j.1365-2664.2005.01004.x

[5] Gilman, R.T., Abell, R.A. and Williams, C.E. (2004) How Can Conservation Biology Inform the Practice of Integrated River Basin Management? International Journal of River Basin Management, 2, 135-148. http://dx.doi.org/10.1080/15715124.2004.9635228

[6] Catford, J.A. and Jansson, R. (2014) Drowned, Buried and Carried Away: Effects of Plant Traits on the Distribution of Native and Alien Species in Riparian Ecosystems. New Phytologist, 204, 19-36. http://dx.doi.org/10.1111/nph.12951

[7] Alexander, S., Nelson, C.R., Aronson, J., Lamb, D., Cliquet, A., Erwin, K.L. and Hobbs, R.J. (2011) Opportunities and Challenges for Ecological Restoration within REDD+. Restoration Ecology, 19, 683-689. http://dx.doi.org/10.1111/j.1526-100X.2011.00822.x

[8] Bayliss, H.R., Schindler, S., Essl, F., Rabitsch, W. and Pullin, A.S. (2015) What Evidence Exists for Changes in the Occurrence, Frequency or Severity of Human Health Impacts Resulting from Exposure to Alien Invasive Species in Europe? A Systematic Map Protocol. Environmental Evidence, 4, 10. http://dx.doi.org/10.1186/s13750-015-0037-4

[9] Pagad, S., Genovesi, P., Carnevali, L., Scalera, R. and Clout, M. (2015) IUCN SSC Invasive Species Specialist Group: Invasive Alien Species Information Management Supporting Practitioners, Policy Makers and Decision Takers. Management of Biological Invasions, 6, 127-135. http://dx.doi.org/10.3391/mbi.2015.6.2.03

[10] Vila, M., Bartomeus, I., Gimeno, I., Traveset, A. and Moragues, E. (2006) Demography of the Invasive Geophyte Oxalis Pes-Caprae across a Mediterranean Island. Annals of Botany, 97, 1055-1062. http://dx.doi.org/10.1093/aob/mcl052

[11] Hejda, M., Pyšek, P. and Jarošík, V. (2009) Impact of Invasive Plants on the Species Richness, Diversity and Composition of Invaded Communities. Journal of Ecology, 97, 393-403. http://dx.doi.org/10.1111/j.1365-2745.2009.01480.x

[12] Armon, R.H. and Zenetos, A. (2015) Invasive Alien Species and Their Indicators. In: Environmental Indicators, Springer, Netherlands, 147-173. http://dx.doi.org/10.1007/978-94-017-9499-2_10

[13] Pejchar, L. and Mooney, H.A. (2009) Invasive Species, Ecosystem Services and Human Well-Being. Trends in Ecology \& Evolution, 24, 497-504. http://dx.doi.org/10.1016/j.tree.2009.03.016

[14] Ehrenfeld, J.G. (2010) Ecosystem Consequences of Biological Invasions. Annual Review of Ecology, Evolution, and Systematics, 41, 59-80. http://dx.doi.org/10.1146/annurev-ecolsys-102209-144650

[15] Lapin, K., Bernhardt, K.-G., Lichtenwöhrer, P. and Roithmayr, S. (2015) Welchen Einfluss haben invasive Pflanzenarten auf die Phytodiversität von renaturierten Flusslandschaften? Gesunde Pflanzen, 67, 75-82. http://dx.doi.org/10.1007/s10343-015-0338-0

[16] MacDougall, A.S. and Turkington, R. (2005) Are Invasive Species the Drivers or Passengers of Change in Degraded Ecosystems? Ecology, 86, 42-55. http://dx.doi.org/10.1890/04-0669

[17] Hood, W.G. and Naiman, R.J. (2000) Vulnerability of Riparian Zones to Invasion by Exotic Vascular Plants. Plant Ecology, 148, 105-114. http://dx.doi.org/10.1023/A:1009800327334

[18] D’Antonio, C. and Meyerson, L.A. (2002) Exotic Plant Species as Problems and Solutions in Ecological Restoration: A Synthesis. Restoration Ecology, 10, 703-713. http://dx.doi.org/10.1046/j.1526-100X.2002.01051.X

[19] Gurnell, A.M., Bertoldi, W. and Corenblit, D. (2012) Changing River Channels: The Roles of Hydrological Processes, Plants and Pioneer Fluvial Landforms in Humid Temperate, Mixed Load, Gravel Bed Rivers. Earth-Science Reviews, 111, 129-141. http://dx.doi.org/10.1016/j.earscirev.2011.11.005

[20] González, E., Sher, A.A., Tabacchi, E., Masip, A. and Poulin, M. (2015) Restoration of Riparian Vegetation: A Global Review of Implementation and Evaluation Approaches in the International, Peer-Reviewed Literature. Journal of Environmental Management, 158, 85-94. http://dx.doi.org/10.1016/j.jenvman.2015.04.033

[21] O’Donnell, J., Fryirs, K.A. and Leishman, M.R. (2016) Seed Banks as a Source of Vegetation Regeneration to Support the Recovery of Degraded Rivers: A Comparison of River Reaches of Varying Condition. Science of the Total Environment, 542, 591-602. http://dx.doi.org/10.1016/j.scitotenv.2015.10.118 
[22] Drescher, A. and Egger, G. (2000) Die Vegetation der Traisenaue zwischen Altmannsdorf und Traismauer (Niederösterreich).

[23] Lapin, K. and Bernhardt, K.G. (2013) The Impact of Alien Plant Species on the Conservation Success of a Protected Natura 2000 Area within the Ecological Restoration of the River Traisen, Lower Austria. 5th Symposium for Research in Protected Areas, Mittersill, 10-12 June 2013, 449-452.

[24] Hein, T., Schwarz, U., Habersack, H., Nichersu, I., Preiner, S., Willby, N. and Weigelhofer, G. (2016) Current Status and Restoration Options for Floodplains along the Danube River. Science of the Total Environment, 543, 778-790. http://dx.doi.org/10.1016/j.scitotenv.2015.09.073

[25] Hering, D., Borja, A., Carstensen, J., Carvalho, L., Elliott, M., Feld, C. and Solheim, A.L. (2010) The European Water Framework Directive at the Age of 10: A Critical Review of the Achievements with Recommendations for the Future. Science of the Total Environment, 408, 4007-4019. http://dx.doi.org/10.1016/j.scitotenv.2010.05.031

[26] Ellmauer, T. and Traxler, A. (2001) Handbuch der FFH-Lebensraumtypen Österreichs. Umweltbundesamt, Wien.

[27] Essl, F., Egger, G., Ellmauer, T. and Aigner, S. (2002) Rote liste gefährdeter biotoptypen Österreichs. Umweltbundesamt, Wien.

[28] Evans, D. (2006) The Habitats of the European Union Habitats Directive. Biology and Environment: Proceedings of the Royal Irish Academy, 106B, 167-173. http://dx.doi.org/10.3318/bioe.2006.106.3.167

[29] Essl, F., Rabitsch, W. and Breuss, O. (2002) Neobiota in Österreich: 432. Umweltbundesamt, Wien.

[30] Kowarik, I. and Säumel, I. (2010) Urban Rivers as Dispersal Corridors for Primarily Wind-Dispersed Invasive Tree Species. Landscape and Urban Planning, 94, 244-249.

[31] Hrázský, Z. (2005) Acer negundo L. in the Czech Republic: Invaded Habitats and Potential Distribution Modeling. Master's Thesis, Faculty of Biological Sciences, University of South Bohemia, České Budějovice.

[32] Kowarik, I. and Säumel, I. (2007) Biological Flora of Central Europe: Ailanthus altissima (Mill.) Swingle. Perspectives in Plant Ecology, Evolution and Systematics, 8, 207-237. http://dx.doi.org/10.1016/j.ppees.2007.03.002

[33] Radtke, A., Ambraß, S., Zerbe, S., Tonon, G., Fontana, V. and Ammer, C. (2013) Traditional Coppice Forest Management Drives the Invasion of Ailanthus altissima and Robinia pseudoacacia into Deciduous Forests. Forest Ecology and Management, 291, 308-317. http://dx.doi.org/10.1016/j.foreco.2012.11.022

[34] Moore, J.J. (1962) The Braun-Blanquet System: A Reassessment. Journal of Ecology, 50, 761-769. http://dx.doi.org/10.2307/2257480

[35] Fischer, M.A. (2008) Exkursionsflora für Österreich, Liechtenstein und Südtirol: Bestimmungsbuch für alle in der Republik Österreich, im Fürstentum Liechtenstein und in der Autonomen Provinz Bozen/Südtirol (Italien) wildwachsenden sowie die wichtigsten kultivierten Gefäßpflanzen (Farnpflanzen und Samenpflanzen) mit Angaben über ihre Ökologie und Verbreitung. Land Oberösterreich, Ö̈. Landesmuseen.

[36] Wäldchen, J., Pusch, J. and Luthardt, V. (2005) Zur Diasporen-Keimfähigkeit von Segetalpflanzen. Beiträge zu Forstwirtschaft und Landschaftsökologie, 38, 145-156.

[37] Karlík, P. and Poschlod, P. (2014) Soil Seed-Bank Composition Reveals the Land-Use History of Calcareous Grasslands. Acta Oecologica, 58, 22-34. http://dx.doi.org/10.1016/j.actao.2014.03.003

[38] Bernhardt, K.G., Koch, M., Kropf, M., Ulbel, E. and Webhofer, J. (2008) Comparison of Two Methods Characterising the Seed Bank of Amphibious Plants in Submerged Sediments. Aquatic Botany, 88, 171-177. http://dx.doi.org/10.1016/j.aquabot.2007.10.004

[39] Shapiro, S.S. and Francia, R.S. (1972) An Approximate Analysis of Variance Test for Normality. Journal of the American Statistical Association, 67, 215-216. http://dx.doi.org/10.1080/01621459.1972.10481232

[40] Royston, P. (1992) Approximating the Shapiro-Wilk W-Test for Non-Normality. Statistics and Computing, 2, $117-119$. http://dx.doi.org/10.1007/BF01891203

[41] Cheung, Y.K. and Klotz, J.H. (1997) The Mann Whitney Wilcoxon Distribution Using Linked Lists. Statistica Sinica, 7, 805-813.

[42] Agresti, A. (1992) A Survey of Exact Inference for Contingency Tables. Statistical Science, 7, 131-153. http://dx.doi.org/10.1214/ss/1177011454

[43] Pysek, P. and Prach, K. (1993) Plant Invasions and the Role of Riparian Habitats: A Comparison of Four Species Alien to Central Europe. Journal of Biogeography, 20, 413-420. http://dx.doi.org/10.2307/2845589

[44] Haag, S., Nobis, M.P. and Krüsi, B.O. (2013) Profitieren invasive Neophyten von Flussrevitalisierungen? Naturschutz und Landschaftsplanung, 45, 357-364.

[45] Tabacchi, E., Correll, D.L., Hauer, R., Pinay, G., Planty-Tabacchi, A.M. and Wissmar, R.C. (1998) Development, Maintenance and Role of Riparian Vegetation in the River Landscape. Freshwater Biology, 40, 497-516. http://dx.doi.org/10.1046/j.1365-2427.1998.00381.x 
[46] Benjankar, R., Egger, G., Jorde, K., Goodwin, P. and Glenn, N.F. (2011) Dynamic Floodplain Vegetation Model Development for the Kootenai River, USA. Journal of Environmental Management, 92, 3058-3070. http://dx.doi.org/10.1016/j.jenvman.2011.07.017

[47] Bottollier-Curtet, M., Planty-Tabacchi, A.M. and Tabacchi, E. (2013) Competition between Young Exotic Invasive and Native Dominant Plant Species: Implications for Invasions within Riparian Areas. Journal of Vegetation Science, 24, 1033-1042. http://dx.doi.org/10.1111/jvs.12034

[48] Kowarik, I. and Starfinger, U. (2003) Biologische Invasionen: Neophyten und Neozoen in Mitteleuropa. Ulmer, Stuttgart.

[49] Woitke, M. and Dietz, H. (2002) Shifts in Dominance of Native and Invasive Plants in Experimental Patches of Vegetation. Perspectives in Plant Ecology, Evolution and Systematics, 5, 165-184. http://www.sciencedirect.com/science/article/pii/S1433831904700578

[50] Hobbs, R.J., Walker, L.R. and Walker, J. (2007) Integrating Restoration and Succession. In: Walker, L.R., Walker, J. and Hobbs, R.J., Eds., Linking Restoration and Ecological Succession, Springer, New York, 168-179. http://dx.doi.org/10.1007/978-0-387-35303-6_8

[51] Dierschke, H. (1994) Pflanzensoziologie: Grundlagen und methoden. Ulmer, Stuttgart.

[52] Wang, N., Jiao, J.Y., Du, H.D., Wang, D.L., Jia, Y.F. and Chen, Y. (2013) The Role of Local Species Pool, Soil Seed Bank and Seedling Pool in Natural Vegetation Restoration on Abandoned Slope Land. Ecological Engineering, 52, 2836. http://dx.doi.org/10.1016/j.ecoleng.2012.12.055

[53] Collins, B. and Wein, G. (1995) Seed Bank and Vegetation of a Constructed Reservoir. Wetlands, 15, 374-385. http://dx.doi.org/10.1007/BF03160892

[54] Buijse, A.D., Coops, H., Staras, M., Jans, L.H., Van Geest, G.J., Grift, R.E. and Roozen, F.C. (2002) Restoration Strategies for River Floodplains along Large Lowland Rivers in Europe. Freshwater Biology, 47, 889-907. http://dx.doi.org/10.1046/j.1365-2427.2002.00915.x

[55] Del Tánago, M.G., De Jalón, D.G. and Román, M. (2012) River Restoration in Spain: Theoretical and Practical Approach in the Context of the European Water Framework Directive. Environmental Management, 50, 123-139. http://dx.doi.org/10.1007/s00267-012-9862-1

[56] Wharton, G. and Gilvear, D.J. (2007) River Restoration in the UK: Meeting the Dual Needs of the European Union Water Framework Directive and Flood Defence? International Journal of River Basin Management, 5, 143-154. http://dx.doi.org/10.1080/15715124.2007.9635314

[57] Foxcroft, L.C., Richardson, D.M., Pyšek, P. and Genovesi, P. (2013) Invasive Alien Plants in Protected Areas: Threats, Opportunities and the Way Forward. In: Foxcroft, L.C., Pyšek, P., Richardson, D.M. and Genovesi, P., Eds., Plant Invasions in Protected Areas, Springer, Dordrecht, 621-639. http://dx.doi.org/10.1007/978-94-007-7750-7_28

[58] Helfield, J.M., Engström, J., Michel, J.T., Nilsson, C. and Jansson, R. (2012) Effects of River Restoration on Riparian Biodiversity in Secondary Channels of the Pite River, Sweden. Environmental Management, 49, 130-141. http://dx.doi.org/10.1007/s00267-011-9773-6 